\title{
The Students' Strategies in Developing Their Ideas in Writing Essay
}

\author{
Dhani Oktavianti \\ IAIN Curup \\ dhanioktavianti2@gmail.com \\ Paidi Gusmuliana \\ IAIN Curup \\ paidigusmuliana@iaincurup.ac.id \\ Eka Apriani \\ IAIN Curup \\ eka.apriani@iaincurup.ac.id
}

\begin{abstract}
This research aimed to find out the students strategies in developing their ideas in writing essay in at fourth semester in IAIN Curup who have best score in writing essay. This research is a descriptive research which is presented in qualitative way. The researcher have two research questions, the research question are: the first what are the students' strategies in developing their ideas in writing essay. The second what are the students' problem in developing their ideas in writing essay. Subject of the research was 10 students at fourth semester on 2019-2020 academic years of English Study Program at IAIN Curup. The instrument of the research was used interview. In analysis data, first researcher identified and check data that be collected. After that, researcher describes all the data. Next the researcher classified the data of the students which is used the strategy or not.
\end{abstract}

Keywords: Students' strategies; ideas; writing essay

\section{A. Introduction}

Writing is a vital skill in English skill because writing needs something perfect such as grammar, and contents or ideas. Good writing ability is really helpful for students in university to finish their study especially in their final task. According to Harmer (2008), writing is used for a wide variety of purposes, it is produced in many different forms which 
conveying their information, idea in written based to grammar, vocabulary because everyone has own many own thinking and it makes they have different perspective to express it. It implies that writing needs perfect English in it with no grammatical mistake and great word choices. To write, the students need to read a lot to get inspiration (Martina, et al. 2020; Martina, et al. 2020)

Writing is a skill that requires to be mastered by each student in university especially for English students for it is the core in writing scientific literature, paper, research, journal, etc (Rahmawati, et al. 2019). Those are the product of one's creativities. Writing can also be broadened the author's knowledge so that students can express their ideas with more freedom. There are various types in writing that the students should focus on it. The types of writing are persuasive, descriptive, expository, and narrative writing.

According to Harmer (2008) there are four main types of writing: persuasive, descriptive, expository and narrative writing. Persuasive writing states the opinion of the writer and attempts to influence the reader. Expository writing in which author's purpose is to inform or explain the subject to the reader. Descriptive writing is a type of expository writing that use the five senses to paint a picture for the reader, this writing incorporates imagery and specific details.

In this research, the researcher focuses on expository writing in particular essay. Essay becomes the focus of this research because essay is the one of writing products that finds it difficult to develop its ideas. In essay per se needs a gorgeous idea to build a good essay and interesting for the reader. In making the reader keeps reading until the end of an essay the content of that essay should impress them as well. 
Jadila: Journal of Development and Innovation in Language and Literature Education

E-ISSN: 2723-6900

Publisher: Yayasan Karinosseff Muda Indonesia

P-ISSN: 2745-9578

Volume:. 1, Number 42021

Page: $389-406$

According to Fournier Paul (1955), essay is short piece of writing on a particular subject, written in order to be published. In other book essay is a composition that expresses the writer's personal view on a single subject. It can be said that essay is vague, overlapping with those of an article or a short story. Essay serves as way to assess your understanding of specific ideas and the ability to explain and argue these to answer a given question. An essay is usually written in prose, in discursive way that brings the idea, arguments, and evidence to answer the said question or solve a problem.

In essay, there are some aspects that need to be paid attention. Those aspects, namely the first aspect is content. Content is the core aspect in writing essay because content is the author's thoughts and ideas. Without it, the writing essay becomes gibberish with no purpose. The second one is the words of choice. Using varied vocabularies will make a piece of writing be more interesting and not monotonous to read. The next aspect is sentence structure. In order to produce a quality of writing, author is to organize his writing, thus sentence structure is essential for this part. The fourth is construction. In the similar manner as of sentence structure, construction is required in order to make the writing organized and easy to understand. The last aspect is the writing mechanism. This aspect includes the use of punctuation, capital letters, and typographical errors.

Based on those aspects above, the researcher concerns about the content of writing essay because content is something that expresses the author's ideas or thoughts. It implies that, in building the content or developing ideas need the great strategy to make an interesting essay for the reader. Furthermore, based on the admission of the lecturer and the document analysis before, the researcher was wondering about the 
strategies that the students used while they were writing an essay. The strategies could make a perfect writing, and then the students may publish their essay on time as an individual assignment in writing class. Accordingly, the researcher was interested to find more information about The Students' Strategies in Developing Writing Essay in English Study Program of IAIN Curup.

\section{B. Theoretical Framework Writing Essay}

According to Cambridge Learner's Dictionary (2015) essay is a short of writing about particular subject, especially one written by a student and writing per se is the skill or activity of producing words on a surface. It means that essay writing is the activity of producing short of written text that can be understood by the readers.

Essay is a piece of writing several paragraphs long instead of just one or two paragraphs (Oshima et al, 1983). According to Susanto Leo (2007), essay is a short piece of writing by a student as part of a course of study. In other part essay is short piece of writing on a particular subject, written in order to be published. In other book essay is a composition that expresses the writer's personal view on a single subject (Paul, 1955). Writing essay has three parts, first as introduction paragraph and consist of two parts (Oshima et al, 1983). There are a few general statements about your subject to attract your readers' attention and a thesis statement to state the specific subdivision of your topic or the "plan" of your paper. A thesis statement for an essay is just like a topic and the controlling ideas or major subdivision of the topic. Leo (2007) in essay writing book introduction contains two main pieces of information. 


\section{Strategies in Developing Students' Ideas in Writing Essay}

Page: $389-406$

Essay is an project for all students in writing college and the essay is independent project, so the students need some strategies in developing their ideas in writing essay. There are some strategies:

\section{Mapping Sometimes Called Clustering Or Webbing.}

Mapping is way of visually analyzing the parts of subject. Mapping is one of the most important preparations for producing quality writing. This technique could help to generate ideas and connect them together. Place individual ideas and connect together in lines. Writer might start with writing the topic in the middle of the page and draw a circle around it. Ideas that are related to your main topic and connect the center circle with line. Third, making a list, that is write single words, phrases, or sentences that are connected to your topic.

\section{Free Writing}

As the same like brainstorming, it occurs intensely for a short period of time and it is unselfconscious. The subject matter does not even have to be related the topic after write something. To look at the words and sense whether or not and really say what you are trying to express. Free writing can help students overcome the sense of block and can even help you get other things off your mind so that you can focus on your assigned topic. Jacobs outlines the nature of free writing as having three important aspects "concentrating on content, not worrying about form, and writing without stopping.

Making a List 
Write single words, phrases, or sentences that are connected to the topic (Dorothy, 2003).

\section{Problems in Developing Writing Essay}

Writing essay is an activity to produce group of paragraph written about single topic consist of thesis statement and supporting paragraph that can be understood by the readers. There are some problems in writing essay stated by Ibrahim Mohamed (2015):
a. Problems organizations.
b. Grammatical problems.
c. Content problems
d. Word choice.

Raimes (1983) thinks that: "When students complain about how difficult it is to write in a second language, they are talking not only about the difficulty of finding the right words and using the correct grammar but also about the difficulty of finding and expressing ideas in a new language".

Therefore, every student must be applied that strategies in writing essay, to solve this problems in his writing. So in this research the researcher will be tried to make a sample for applying the strategies in developing their ideas in writing essay.

\section{Research Methodology}

This research uses descriptive method with qualitative way. Generally, researcher will be present the result of the research with the real data without adding a writer's assumption or argument. According to Hancock (Hancock, 1998) explain that qualitative research is concerned 
with developing explanations of social phenomena, it is describes social phenomena as they occur naturally.

The subject of the research is the students of English Study Program at IAIN Curup. In this case the researcher used purposive sampling because the researcher taken the data from 10 students who have the best score of writing. Purposive sampling seeks information-rich cased that can be studied in depth (Hoepfl, 2009). The subjects of this research are 62 students' of fourth semester at IAIN Curup. The researcher used 15 students' as subject who are taken based on the best in writing essay score, but just 10 students could be interview to this research.

In this research, the researcher use interview as the technique of data collecting. During this research, the researcher used structured interview to gather data. The research will be done by interviewing the students' about students' strategy in developing idea in writing essay. Within the process researcher used the interview guidance with voice note by social media WhatsApp. So that, researcher collect the data by interviewing designated students as research subject.

After the collecting the data, the researcher continued to analyze this data. (Creswell, 2014) said that for analyzing qualitative data, the researcher can doing to manage the data, reading a script of the interview with the students involved, describing the results of the interview, classifying the script of interview according to the data we are want, interpreting the goals or intent of the students answer of the interview and representing the data generated from the interview, the findings in a written report. 


\section{Result and Discussion}

\section{Result}

Students' Strategies in Developing Their Ideas in Writing Essay

Table 1: Students' Strategies in Developing Their Ideas in Writing Essay

\begin{tabular}{|c|c|c|}
\hline No. & Students & Strategies \\
\hline 1. & Student A & $\begin{array}{ll}\text { - } & \text { Make a mapping } \\
\text { - } & \text { Free writing } \\
\text { - } & \text { Listing Ideas } \\
\end{array}$ \\
\hline 2. & Student B & $\begin{array}{ll}\text { - } & \text { Make a listing Ideas } \\
\text { - } & \text { Make a mapping }\end{array}$ \\
\hline 3. & Student C & $\begin{array}{ll}\text { - } & \text { Make a mapping } \\
\text { - } & \text { Free writing }\end{array}$ \\
\hline 4. & Student D & $\begin{array}{ll}- & \text { Free writing } \\
- & \text { Make a listing ideas }\end{array}$ \\
\hline 5. & Student E & $\begin{array}{ll}\text { - } & \text { Make a mind mapping } \\
\text { - } & \text { Free writing }\end{array}$ \\
\hline 6. & Student F & $\begin{array}{ll}\text { - } & \text { Make mind mapping } \\
- & \text { Make a listing ideas } \\
- & \text { Free writing }\end{array}$ \\
\hline 7. & Student $\mathrm{G}$ & $\begin{array}{ll}- & \text { Make a listing Ideas } \\
\text { - } & \text { Make a mind mapping } \\
\text { - } & \text { Free writing }\end{array}$ \\
\hline 8. & Student H & $\begin{array}{ll}- & \text { Free writing } \\
- & \text { Make a listing Idea } \\
- & \text { Make mind mapping }\end{array}$ \\
\hline 9. & Student I & $\begin{array}{ll}\text { - } & \text { Make a listing Idea } \\
\text { - } & \text { Free writing }\end{array}$ \\
\hline 10. & Student J & $\begin{array}{ll}\text { - } & \text { Make a listing Idea } \\
\text { - } & \text { Make mind mapping } \\
- & \text { Free writing }\end{array}$ \\
\hline
\end{tabular}

Based on the table above the researcher concluded that the application of these strategies greatly affects students in developing their 
Jadila: Journal of Development and Innovation

E-ISSN: 2723-6900

in Language and Literature Education

P-ISSN: 2745-9578

Publisher: Yayasan Karinosseff Muda Indonesia

Volume:. 1, Number 42021

Page: $389-406$

writing ideas, and facilitates writing lecturers in learning process of fourth semester.

First, the researcher concluded that the student who used some of the strategies in developing his ideas in writing essay could do well in accomplishing his goal. He started his essay with Free writing. After that, he made a mind mapping and list of ideas to develop the ideas in writing essay. The implementation of the strategies helped him overcome his writing problem. Leo Susanto (2007) said that strategies are used to make the problem easier to understand and solve. The students benefited greatly from implementing the strategies that the improvement was quite significant

Second, the researcher summarized that the student $\mathrm{B}$ who implemented the strategies make a mind mapping and listing ideas to developing their ideas in writing essay, succeeded develop the ideas when she implemented the strategy.

Third, student $\mathrm{C}$ applied some strategies to develop their ideas in writing an essay. She made a mind mapping to develop ideas, after that she carried out free writing to write her essay.

Fourth, student D used some of the strategies to develop their ideas in writing an essay. She followed some of the strategies such as listing ideas. Then, she applied free writing to develop ideas.

Fifth, student $\mathrm{E}$ applied the strategies in developing their ideas in writing an essay. He made a mind mapping and conducted free writing to express new ideas, therefore making the essay interesting to read by the readers.

Sixth, the student used all of the strategies in developing ideas in writing an essay. She applied the strategies and made mind mapping so that 
Jadila: Journal of Development and Innovation

E-ISSN: 2723-6900

in Language and Literature Education

P-ISSN: 2745-9578

Publisher: Yayasan Karinosseff Muda Indonesia

Volume:. 1, Number 42021

Page: $389-406$

the concept of the writing can be structured. After that, she also made a list of ideas, after that she conducted free writing to express the new ideas.

Seventh, the students used some of the strategies in developing their ideas in writing an essay. According to the student, he always used the strategies like making a list of ideas, mind mapping to develop the ideas, and conducted free writing to express the new ideas.

Eight, the researcher can conclude that the student used some strategies in developing their ideas in writing essays. The strategies are making a list of ideas and mind mapping and conducting free writing to express all the ideas. So, every student used all of the strategies in developing their ideas in writing essays, and they are allowed to just used some of them only because every student's abilities are different..

Ninth, student I used all of the strategies in developing his ideas in writing essays. The student made a list of ideas and conducted free writing to develop and express the new ideas.

The last, based on the table above the researcher concluded that the student used all of the strategies in developing their ideas in writing essays. When the student used all of the strategies the result of their essay will be a perfect writing essay in the college. She made a list of the ideas made a mind mapping to develop ideas from the list, and the last does free writing before made an essay to developing the ideas in writing essays.

Students' Problems in Developing Their Ideas in Writing Essay Table 2: Students' Problems in Developing Their Ideas in Writing Essay

\begin{tabular}{|c|c|c|}
\hline No. & Students' & Problems \\
\hline 1. & Student A & $\begin{array}{ll}- & \text { Problems organization. } \\
\text { - } & \text { Grammatical problems. }\end{array}$ \\
\hline
\end{tabular}




\begin{tabular}{|c|c|c|}
\hline 2. & Student B & $\begin{array}{ll}\text { - } & \text { Grammatical problems. } \\
\text { - } & \text { Word choice }\end{array}$ \\
\hline 3. & Student C & $\begin{array}{ll}\text { - } & \text { Problems organization. } \\
\text { - } & \text { Word Choice }\end{array}$ \\
\hline 4. & Student D & Have no problems \\
\hline 5. & Student E & - Content problems \\
\hline 6. & Student F & $\begin{array}{ll}- & \text { Content problems } \\
\text { - } & \text { Grammatical problems }\end{array}$ \\
\hline 7. & Student $\mathrm{G}$ & $\begin{array}{ll}- & \text { Word choice } \\
\text { - } & \text { Grammatical problems }\end{array}$ \\
\hline 8. & Student $\mathrm{H}$ & - Grammatical problems \\
\hline 9. & Student I & - Grammatical problems \\
\hline 10. & Student J & $\begin{array}{ll}\text { - } & \text { Grammatical problems } \\
\text { - } & \text { Problem organizations }\end{array}$ \\
\hline
\end{tabular}

The first, based on the table above, the researcher concluded that student A faced some problems in developing his ideas in writing an essay, i.e. the organization of the essay, sentence structure or grammatical problem, and fear of failure when he wrote the essay. The student implemented the strategies so that the problems could be overcome.

Second, the researcher concluded that student B faced some problems in developing his ideas in writing an essay e.g. she was confused with the grammatical structures and selecting the proper words of choice, making it difficult to develop the idea, and fear of failure in writing an essay. The researcher concluded that every student have any problem in developing their ideas in writing essay. 
Third, the researcher found that the student faced some problems in writing his essay, the problem is developing words into sentences, the evidence did not match the essays made, she had problems in constructing the introduction or problems of organization and she solve it by looking at an example of an essay that existed before, she had a problem with the organization of the essay, the way to overcome this is to look for sources of reference related to the essay that will be made, both from books and scientific journals, she also faced problem in word choice so that she felt stuck there, writing essays sometimes arises fear and failure, because of inaccurate sources in writing essays and sentences that are not coherent. The way to overcome this is to read more examples of essays and try to become a better writer.

Fourth, based on the table above we can conclude that she had a little problem in developing her ideas in writing ideas. For her, beginning authorship is the most difficult thing than the others and write the conclusion, shortening the essence of what she wrote is a clear conclusion. And the last she said that during this time I have not found that fear. Because what I'm doing is still writing ordinary essays. As long as I write an essay, I always seem to be able to do it well. So, every student has different ability in developing their ideas in writing essay.

Fifth, based on the table above, we can conclude that he had problems in developing his ideas in writing the essay, if he made the thesis statement he made wrong it, he got problems with the content of the essay, because he had the fair failure.

Sixth, based on the table above the researcher concluded that she has some problems like, when she wrote the content she found some difficulties and she has problems with the grammatical sentences. So that 
she thinks she has many problems in writing the essay, after that she has a problem when she makes references after writing the essay, one of the difficulties for her is sentence structure or grammatical problems, and then, she also felt the fear of failure when she is writing the essay. So that, the lecturer and students must overcome those problems in order to be a good writer and to produce a perfect essay.

Seventh, based on the table above the researcher concluded that the students have some problems in developing their ideas in writing essay. Like students $\mathrm{G}$, he has problems that problems are: grammatical problems and word choice in this essay.

Eight, based on the table above the researcher can conclude that the students have little problem in developing their ideas in writing essay. That problem is grammatical problems because she feels her written is unorganized, so drafting and listing can help and she also has the fear of failure in writing essay. So that we can conclude that not all the students have much problem in developing their ideas in writing essay, the students have no problem in developing their ideas.

Ninth, based on the table above we can conclude that the students just have one problem in developing their ideas in writing essay, that problem is sentences structure or grammatical problems. So, the researcher concluded that the students just need try to make the sentences good to repair their problem in developing their ideas in writing essay.

Tenth, Based on the table above the researcher concluded that the student have some problem in developing their ideas in writing essay. The student's problem is, she has problem with sentence structure or grammatical problems she found it hard to find the words that are commensurate with the words she wanted to write because writing must 
require a variety of languages so that the readers do not get bored to overcome them. She searched the words in online dictionary that she has about for intense conjunction or prepositions that she wanted to use. She also has problem when she constructed the introduction or the organization of essay. And the last she has problem with organizations of essay, she is fear of that the essays that she had written cannot attract the readers, what she was done to overcome this is to make essays that are interesting and as good as possible starting from the determination of the title and using facts and interesting stories.

\section{Discussion}

\section{Students' Strategies in Developing Their Ideas in Writing Essay}

Based on the statement of 10 students as a subject of the research, the researcher found some students have many strategies in developing their ideas in writing essay and also students have many strategies in developing their ideas in writing essay. Students strategies in developing their ideas in writing essay on fourth semester in IAIN Curup 2019/2020 academic years had been implemented and used the strategies in developing their ideas in writing essay such as students B, E, F, G, I, J, they all used all the strategies by Dorothy (2003).

Thus, based on the finding of the students A, B, C, D, E, F, G, H, I, $\mathrm{J}$, in students strategies in developing their ideas in writing essay, some students often use the strategies in developing their ideas such as they use make a list strategy because with list their essay could be arranged, will be facility in developing their ideas. Based on Ann Raimes (2005) said that the technique can help you generate ideas and connect them together. Place individual ideas in boxes and connect them together with lines. Add 
Jadila: Journal of Development and Innovation

E-ISSN: 2723-6900

in Language and Literature Education

P-ISSN: 2745-9578

Publisher: Yayasan Karinosseff Muda Indonesia

Volume:. 1, Number 42021

Page: 389-406

additional boxes with ideas that are related to your main topic and connect them to the center circle with lines. So that, the using diagram strategy will be developed their ideas in writing essay.

Furthermore, the students also mind mapping in developing their ideas in writing essay because can give some inspiration from the writing so that they can further develop the idea with using that strategy in writing essay. So that according to the interview with the students, using this strategy very helpful in developing their ideas in writing essay, because the strategy can inspire and information that strengthens the evidence in their writing so it could be referral material.

Moreover, the student used free writing strategy in developing their ideas in writing essay, they said that using that strategy would be helped in developing their ideas and words that they would use in writing essay. Free writing also can bring out the idea ever thought of a topic discussion, so when they write the essay they would be better in developing their ideas in writing essay and they do not have problems. Free writing is helpful in this regard, so it is recommended to use in writing an essay.

From the explanation above, the researcher could conclude that not all the strategy would be made the students in developing their ideas in writing essay, the strategies which is used the students are, free writing, diagramming, and looking to the models.

\section{Students' Problems in Developing Their Ideas in Writing Essay}

Based on the research above the researcher concluded that the students have problems in developing their ideas in writing essay. That the problems are: unable to write thesis statement, the student said that they made a wrong the thesis statement, whereas the thesis statement is one part of the process for writing an essay. Thesis statement is a part of an essay, if 403 
an essay has not thesis statement so the reader questions the truthfulness of the content of the essay, so it cannot be used as a reference.

Furthermore, the students problems is lack of writer motivations it is very influential in the resulting writing, when students do not have the motivations to write an essay then, the students would have difficulties to express their ideas. They also have problem when writing the introduction and organizations problems, lack of relevant references, awkward structure or grammatical problems, according to Tyner (1987) sentence structure learners have a number of problems in their attempts to write in the foreign language "As verbs take different forms depending on tense and subjects they are used with, they create problems for second language writing students". Similarly, Kharma (2007) in Melese states that students have problems with subject verb agreements, pronoun references, and connectors. Students have problems with the word choice, the content of the writing and fear of failure.

Furthermore, some students can solve the problems by their own way for made their product is to be good essay. While students still have many problems in developing their ideas in writing essay, such as grammatical problems, organization problems, content problems, and word choice.

\section{E. Conclusion}

Based on the finding and discussion it could be concluded that First, there are six strategies in developing their ideas in writing essay. Based on the research, the researcher find that the student is not used all the strategy in developing their ideas in writing essay. It can be caused by some strategy which is can develop their ideas. 
Second, there are some problems in developing their ideas in writing essay. The prime of the problems for the students is lack of writer motivations, and awkward structure or grammatical problems. In writing essay the students also have another problems such as write the thesis statement, problems of the content word choice. As suggestion, it will conduct the research in this areas, the writer hope the other time, the researcher can investigate more about the student strategies in developing their ideas in writing essay. So that the students will be easier in developing their ideas in writing essay, and can be complete their task.

\section{References}

Allice, O., \& Hongue, A. (1983). Writing academic English. Adison Wisely Publishing Company : Massach Ussets MA.

Creswell, J.W. (2014). Qualitative Inquiry and research design choosing among five approach. California: Sage Publication.

Guy, B., \& Tinker. (1990). Reading And difficulties their diagnosis and correcting, USA: Appation, crooff.inc.

Hancock, B. (1998). Trent Focus for research and development in primary health carte: an Introduction to qualitative research.

Harmer, J. (2008). How to teach English. ELT journal, 62(3), 313-316.

Hoepfl, C.M. (2009). Choosing qualitative research, a Prime For Technology Education Research. Journal of International Journal of Therapy and Rehabilitation, 6(1), 25.

Martina, F., Syafryadin, S., \& Utama, J. A. (2020). The Practice of extensive reading among EFL learners in tertiary level. Yavana Bhasha: Journal of English Language Education, 3(2), 56-72. 
Martina, F., Syafryadin, S., Rakhmanina, L., \& Juwita, S. (2020). The effect of time constraint on student reading comprehension test performance in narrative text. Journal of Languages and Language Teaching, 8(3), 323-329.

Oxford, R. (1990). Taxonomy of strategies. Oxford.

Paul, F. (1995). Strategies for correct writing, library of congress cataloguing in publication data, Amerika

Rahmawati, I. N., Syafryadin, S., \& Widiastuti, R. (2019). Teaching narrative writing using freaky fables game: an experimentation. English Education: Jurnal Tadris Bahasa Inggris, 12(2), 147-155.

Sugiyono. (2001). Metode penelitian kombinasi. Bandung: Alfabeta.

Leo, S. (2007). Essay writing. C.V ANDI offset, Jakarta. 